\author{
Organocatalytic Direct Asymmetric Aldol Reactions in Water \\ Nobuyuki Mase, ${ }^{\dagger}$ Yusuke Nakai, ${ }^{\dagger}$ Naoko Ohara,${ }^{\dagger}$ Hidemi Yoda, ${ }^{\dagger}$ Kunihiko Takabe, ${ }^{*}, \dagger$ \\ Fujie Tanaka, ${ }^{\ddagger}$ and Carlos F. Barbas III*,‡ \\ Department of Molecular Science, Faculty of Engineering, Shizuoka University, 3-5-1 Johoku, Hamamatsu \\ 432-8561, Japan and The Skaggs Institute for Chemical Biology and the Departments of Chemistry and Molecular \\ Biology, The Scripps Research Institute, 10550 North Torrey Pines Road, La Jolla, California 92037
}

Received October 27, 2005; E-mail: tcktaka@ipc.shizuoka.ac.jp; carlos@scripps.edu

Catalytic asymmetric reactions that can be performed in water are of current interest, because water is a desirable solvent with respect to environmental concerns, safety, and cost. ${ }^{1}$ However, the use of water as reaction solvent is not always practical for asymmetric catalytic reactions because water often inhibits the catalyst's activity or alters enantioselectivity by interrupting ionic interactions and hydrogen bonds critical for stabilizing the transition states of the reactions. ${ }^{1}$ Thus, special design is required for performing asymmetric reactions in water. Here we report efficient enamine-based organocatalytic direct asymmetric aldol reactions in water without any organic cosolvent. Reactions afforded the desired products in high yields with high enantioselectivities using an amine-acid bifunctional catalyst.

Organocatalytic asymmetric aldol reactions via in situ generated enamine intermediates are useful $\mathrm{C}-\mathrm{C}$ bond-forming reactions and yield aldol products with excellent enantioselectivities. ${ }^{2}$ These reactions are typically performed in organic solvents, such as DMSO, DMF, or chloroform, under mild conditions. Although addition of a small amount of water often accelerates reactions and/ or improves enantioselectivities, ${ }^{3}$ addition of a large amount of water or aqueous buffer as reaction solvent has typically resulted in low yield with low or no enantioselectivity. ${ }^{2 \mathrm{a}, 3 \mathrm{~b}, 4}$ In contrast, natural Class I aldolase enzymes ${ }^{5}$ and aldolase catalytic antibodies ${ }^{6}$ that use an enamine mechanism catalyze enantioselective aldol reactions in water. In the aldolase antibodies, the reactions occur in a hydrophobic active site, ${ }^{6}$ indicating that diminishing contacts between bulk water and the reaction transition states may be critical for high enantioselectivities. Thus, we hypothesized that a small organic catalyst with appropriate hydrophobic groups should assemble with hydrophobic reactants in water and sequester the transition state from water. As a result, the outcome of the reaction should be similar to that performed in organic solvents. To test this hypothesis, the aldol reaction of cyclohexanone (1a) and $p$-nitrobenzaldehyde (2a) to afford 3a was performed in water using several amine catalysts bearing hydrophobic alkyl chains in the presence or absence of additives. While the organocatalytic aldol reaction between $\mathbf{1 a}$ and $\mathbf{2 a}$ has typically been performed using a large excess of $\mathbf{1 a},{ }^{2 \mathrm{a}, 4}$ here, only 1 or 2 equiv of cyclohexanone to the aldehyde were used. The results are shown in Table 1.

Although L-proline (4) catalyzed the aldol reaction in DMSO (entry 1), no reaction progress was detected after 4 days in water (entry 2). (S)-Prolinol (5) and amide catalyst $6 \mathbf{6}$ both catalyzed the reaction, but low enantioselectivities were observed (entries 3 and 4). The reaction with amide catalysts $\mathbf{6 b}$ or $\mathbf{7}$ bearing long alkyl groups afforded better enantioselectivity than the reaction with $\mathbf{6 a}$, but the enantiomeric excess was still poor (entries 5 and 6). Diamine $\mathbf{8} \mathbf{a}$ also afforded product $\mathbf{3 a}$ in quantitative yield in water without an acid additive, but the product was racemic (entry 7). Diamine

\footnotetext{
Shizuoka University.

\$ The Scripps Research Institute.
}

Table 1. Screening of Catalysts in the Direct Asymmetric Aldol Reaction of Cyclohexanone (1a) with $p$-Nitrobenzaldehyde (2a) in Water $^{a}$

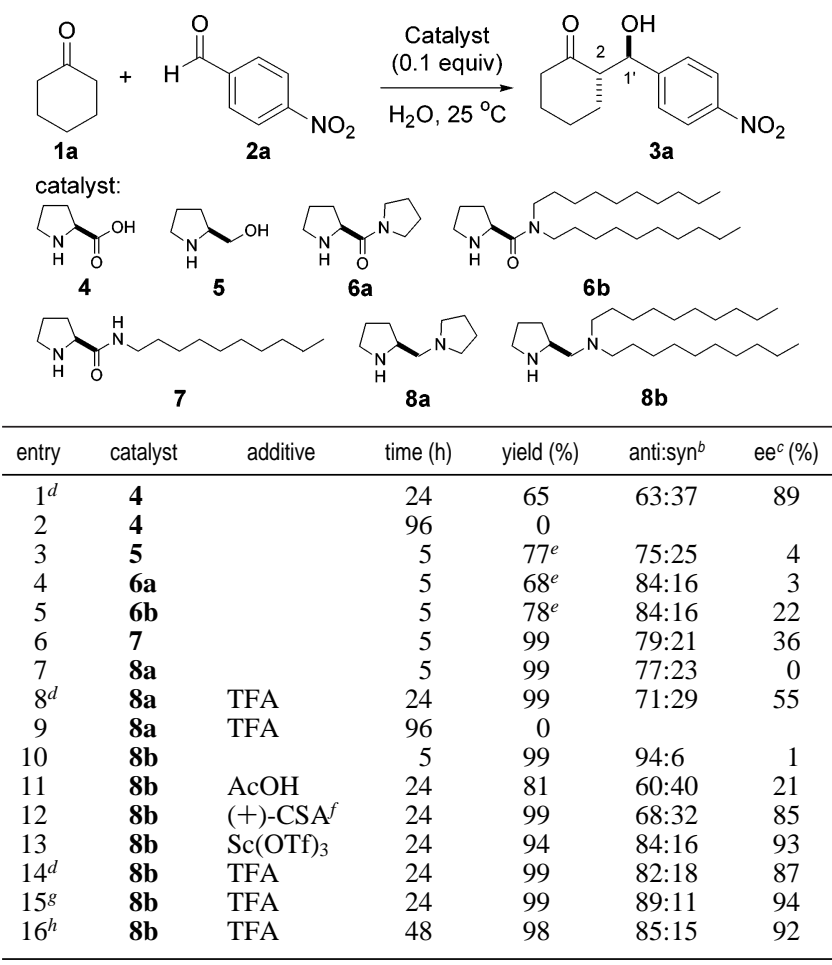

${ }^{a}$ Conditions: Amine catalyst $(0.05 \mathrm{mmol})$, additive (if used, $\left.0.05 \mathrm{mmol}\right)$, 1a $(1.0 \mathrm{mmol})$, and $2 \mathrm{a}(0.5 \mathrm{mmol})$ in water $(1.0 \mathrm{~mL})$. ${ }^{b}$ Determined by ${ }^{1} \mathrm{H}$ NMR of the crude product. ${ }^{c}$ Determined by chiral-phase HPLC analysis for anti-product. ${ }^{d}$ The reaction was carried out in DMSO. ${ }^{e}$ Aldehyde 2 a recovery was $21 \%, 18 \%$, and $11 \%$, respectively. ${ }^{f_{\mathrm{D}}}(+)-10$-Camphorsulfonic acid. ${ }^{g}$ See ref $9 .{ }^{h}$ Donor $1 \mathrm{a}(0.5 \mathrm{mmol}, 1$ equiv) was used.

8a with trifluoroacetic acid (TFA) 7 efficiently catalyzed the reaction in DMSO but not in water (entries 8 and 9).

The best result with respect to yield, diastereoselectivity, and enantioselectivity was observed with catalyst $\mathbf{8 b}^{8}$ and TFA additive (entry 15). In water without any additive, the reaction with $\mathbf{8 b}$ gave 3a in good yield with high diastereoselectivity but with almost no enantioselectivity (entry 10). Addition of TFA to the reaction with 8b significantly improved the enantioselectivity to $94 \%$ ee for anti3a (entry 15). ${ }^{9}$ Addition of a Lewis acid, such as scandium trifluoromethanesulfonate, to the reaction catalyzed by $\mathbf{8 b}$ afforded the product 3a with 93\% ee (entry 13). Strong acids provided higher enantioselectivities than a weak acid (entries $12-15$ vs 11 ). The results of the $\mathbf{8 b}$ /TFA-catalyzed reaction in water vs DMSO were similar; the reaction in water afforded slightly higher diastereoand enantioselectivities than that in DMSO (entry 14 vs 15). The diastereoselectivity of the $\mathbf{8 b}$ /TFA-catalyzed reaction was higher than that of the L-proline-catalyzed reaction (entry 1 vs 15 ). ${ }^{2 a, 4 e}$ In 
Table 2. Diamine 8b/TFA-Catalyzed Aldol Reactions of 1a with Various Arylaldehydes 2 in Water ${ }^{a}$

\begin{tabular}{|c|c|c|c|c|c|c|}
\hline entry & $x$ & product & time $(\mathrm{h})$ & yield $(\%)$ & anti:syn ${ }^{b}$ & $\mathrm{ee}^{c}(\%)$ \\
\hline 1 & $4-\mathrm{CN}$ & 3b & 48 & 99 & $86: 14$ & 87 \\
\hline 2 & $4-\mathrm{CO}_{2} \mathrm{Me}$ & 3c & 48 & 89 & $90: 10$ & 91 \\
\hline 3 & $4-\mathrm{Br}$ & 3d & 72 & $43^{d}$ & $91: 9$ & 97 \\
\hline 4 & 4-Cl & $3 \mathbf{e}$ & 72 & $74^{d}$ & $88: 12$ & 90 \\
\hline 5 & $4-\mathrm{H}$ & $3 f$ & 72 & 46 & $90: 10$ & 99 \\
\hline 6 & 4-OMe & $3 \mathrm{~g}$ & 72 & 5 & $86: 14$ & 96 \\
\hline 7 & $3-\mathrm{NO}_{2}$ & 3h & 24 & 99 & $90: 10$ & 99 \\
\hline 8 & $2-\mathrm{NO}_{2}$ & 3i & 24 & 98 & $89: 11$ & 98 \\
\hline
\end{tabular}

${ }^{a}$ See ref 9. ${ }^{b}$ Determined by ${ }^{1} \mathrm{H}$ NMR of the crude product. ${ }^{c}$ Determined by chiral-phase HPLC analysis for anti-product. ${ }^{d}$ Aldehyde was recovered in $40 \%$ and $18 \%$, respectively.

addition, the amount of donor cyclohexanone could be decreased to 1 equiv relative to the acceptor aldehyde without compromising the results (entry 16). This is a significant improvement over the conventional aldol reaction in organic solvents, in which a considerable excess of donor (20 vol \%, 19 equiv) was used. ${ }^{2-4}$ Furthermore, crude aldol products were easily isolated by removal of water using centrifugal separation.

These results indicate that neither an acid functionality on the pyrrolidine derivatives nor an acid additive are required for catalysis of the aldol reaction in water. When catalyst or catalyst additive included an acid but not a hydrophobic alkyl chain, the reaction did not proceed in water. This may be because both catalyst and additive are soluble, whereas reactants are less miscible in water. In a biphasic system, interactions required for reaction do not occur. In the case of the reaction using $8 \mathbf{b} / \mathrm{TFA}$, the catalyst additive assembles with the reactants through hydrophobic interactions, excluding water molecules from the organic phase. ${ }^{10}$ In this concentrated organic phase the reaction occurs efficiently to afford 3a with high enantioselectivity, presumably facilitated by hydrogen bonds between the enamine-8b/TFA ammonium salt and the acceptor in the transition state. In fact, the reaction mixture containing 1a, 2a, and 8b/TFA was not biphasic but was an emulsion (see Supporting Information). Note that L-proline- or 8acatalyzed aldol reactions in aqueous micelles using surfactants, such as sodium dodecyl sulfate (SDS), only gave racemic products. ${ }^{4 a, c}$

The major product 3a generated from the $\mathbf{8 b}$ /TFA-catalyzed reaction had $\left(2 S, 1^{\prime} R\right)^{2 a}$ absolute stereochemistry. Therefore, the enamine intermediate of the $\mathbf{8 b}$ /acid-catalyzed reaction favored a $r e$-facial attack on the arylaldehyde. This reaction mode is in accord with that of diamine $\mathbf{8 a}$ /acid-catalyzed and L-proline-catalyzed aldol reactions in DMSO. ${ }^{2 a, 7,11}$

The scope of this class of aldol reactions using diamine $8 \mathrm{~b} / \mathrm{TFA}$ catalyst in water was examined with a series of arylaldehyde acceptors (Table 2) and ketone and aldehyde donors (Table 3 ). In most cases, reactions afforded anti-aldol products in high yields with excellent enantioselectivities (Table 2). Reactions with water miscible ketones yielded the products in moderate yield even when 0.3 equiv of catalyst was used (Table 3 , entries 3 and 4), while quantitative yield was observed in the reaction with less miscible 2 -octanone (entry 5). The reaction of isobutyraldehyde yielded $\alpha, \alpha$ dialkyl aldol product 3o, with no formation of self-aldol product, and with similar high enantioselectivity compared with the reaction in DMSO (entry 6).

In summary, we have developed a catalytic direct asymmetric aldol reaction that can be performed in water without addition of organic solvents. The diamine $\mathbf{8 b}$ /TFA bifunctional catalyst system
Table 3. Diamine $8 b / T F A-C a t a l y z e d$ Aldol Reactions of Various Ketones and Aldehyde $\mathbf{1}$ with $\mathbf{2 a}$ in Water ${ }^{a}$

\begin{tabular}{|c|c|c|c|c|c|c|c|}
\hline entry & $\mathrm{R}^{1}$ & $\mathrm{R}^{2}$ & product & time $(\mathrm{h})$ & yield (\%) & anti:syn ${ }^{b}$ & $\mathrm{ee}^{c}(\%)$ \\
\hline 1 & $-\left(\mathrm{CH}_{2}\right)_{3}-$ & & $3 \mathbf{j}$ & 24 & 98 & $61: 39$ & 87 \\
\hline $2^{d}$ & $-\left(\mathrm{CH}_{2}\right)_{5}-$ & & $3 \mathbf{k}$ & 72 & 40 & $46: 54$ & $99^{e}$ \\
\hline $3^{d}$ & $\mathrm{Me}$ & $\mathrm{H}$ & 31 & 72 & $82^{f}$ & & 55 \\
\hline $4^{d}$ & Et & $\mathrm{H}$ & $3 \mathbf{m}$ & 72 & $49^{f}$ & & 54 \\
\hline 5 & $n \mathrm{Hex}$ & $\mathrm{H}$ & $3 n$ & 72 & $99^{g}$ & & $22^{g}$ \\
\hline 6 & $\mathrm{H}$ & note $^{h}$ & 30 & 72 & $99^{i}$ & & $91^{i}$ \\
\hline
\end{tabular}

${ }^{a}$ See ref $9 .{ }^{b}$ Determined by ${ }^{1} \mathrm{H}$ NMR of the crude product. ${ }^{c}$ Determined by chiral-phase HPLC analysis for anti-product. ${ }^{d}$ Catalyst ( 0.3 equiv) was used. ${ }^{e}$ For syn-product. Anti-product was obtained with $23 \%$ ee. ${ }^{f}$ Aldehyde 2a recovery was $10 \%$ and $45 \%$, respectively. ${ }^{g}$ In DMSO, $14 \%$ yield, $29 \%$ ee. ${ }^{h}$ Isobutyraldehyde was used as a donor. ${ }^{i}$ In DMSO, $96 \%$ yield, $90 \%$ ee.

demonstrated excellent reactivity, diastereoselectivity, and enantioselectivity in water. Further studies focusing on the full scope of this catalyst-aqueous media system and related systems are currently under investigation and will be reported in due course.

Acknowledgment. This study was supported in part by a Grantin-Aid (No.16550032) from Scientific Research from the Japan Society for the Promotion of Science and The Skaggs Institute for Chemical Biology.

Supporting Information Available: Experimental procedures and HPLC data and a photograph of the reaction mixture. This material is available free of charge via the Internet at http://pubs.acs.org.

\section{References}

(1) (a) Lindstrom, U. M. Chem. Rev. 2002, 102, 2751-2772. (b) Kobayashi, S.; Manabe, K. Acc. Chem. Res. 2002, 35, 209-217. See also references therein.

(2) (a) Sakthivel, K.; Notz, W.; Bui, T.; Barbas, C. F., III J. Am. Chem. Soc. 2001, 123, 5260-5267. (b) Northrup, A. B.; MacMillan, D. W. C. J. Am Chem. Soc. 2002, 124, 6798-6799. (c) Notz, W.; Tanaka, F.; Barbas, C. F., III. Acc. Chem. Res. 2004, 37, 580-591. (d) Suri, J. T.; Ramachary, D. B.; Barbas, C. F., III. Org. Lett. 2005, 7, 1383-1385.

(3) (a) Torii, H.; Nakadai, M.; Ishihara, K.; Saito, S.; Yamamoto, H. Angew. Chem., Int. Ed. 2004, 43, 1983-1986. (b) Nyberg, A. I.; Usanp, A.; Pihko, P. M. Synlett 2004, 1891-1896.

(4) (a) Cordova, A.; Notz, W.; Barbas, C. F., III. Chem. Commun. 2002, 3024-3025. (b) Darbre, T.; Machuqueiro, M. Chem. Commun. 2003 1090-1091. (c) Peng, Y.-Y.; Ding, Q.-P.; Li, Z.; Wang, P. G.; Cheng, J.-P. Tetrahedron Lett. 2003, 44, 3871-3875. (d) Wu, Y.-S.; Shao, W.Y.; Zheng, C.-Q.; Huang, Z.-L.; Cai, J.; Deng, Q.-Y. Helv. Chim. Acta 2004, 87, 1377-1384. (e) Wu, Y.-S.; Chen, Y.; Deng, D.-S.; Cai, J. Synlett 2005, 1627-1629. (f) Chimni, S. S.; Mahajan, D.; Suresh Babu, V. V. Tetrahedron Lett. 2005, 46, 5617-5619. (g) Small peptides were used to catalyze asymmetric aldol reactions with high enantioselectivities in aqueous media: Tang, Z.; Yamg, Z.-H.; Cun, L.-F.; Gong, L.-Z.; Mi, A.-Q.; Jiang, Y.-Z. Org. Lett. 2004, 6, 2285-2287.

(5) Heine, A.; DeSantis, G.; Luz, J. G.; Mitchell, M.; Wong, C.-H.; Wilson, I. A. Science 2001, 294, 369-374.

(6) Zhu, X.; Tanaka, F.; Hu, Y.; Heine, A.; Fuller, R.; Zhing, G.; Olson, A. J.; Lerner, R. A.; Barbas, C. F., III; Wilson, I. A. J. Mol. Biol. 2004, 343 $1269-1280$ and references therein.

(7) Diamine 8a/acid bifunctional catalysts catalyzed aldol reactions with high enantioselectivities in conventional organic solvents. (a) Nakadai, M.; Saito, S.; Yamamoto, H. Tetrahedron 2002, 58, 8167-8177. (b) Mase, N.; Tanaka, F.; Barbas, C. F., III. Angew. Chem., Int. Ed. 2004, 43, 24202423.

(8) Betancort, J. M.; Sakthivel, K.; Thayumanavan, R.; Tanaka, F.; Barbas, C. F., III. Synthesis 2004, 1509-1521.

(9) The diamine $\mathbf{8 b} /$ TFA-catalyzed reaction in water: To a mixture of diamine $\mathbf{8 b}(0.05 \mathrm{mmol})$ in water $(1.0 \mathrm{~mL})$ trifluoroacetic acid $(0.05 \mathrm{mmol})$ was added at $25{ }^{\circ} \mathrm{C}$ under air. The reaction mixture was stirred for $3 \mathrm{~min}$ in a closed system, and ketone $(1.0 \mathrm{mmol})$ and aldehyde $(0.5 \mathrm{mmol})$ were added. The reaction mixture was vigorously stirred for the indicated time. Removal of water by centrifugal separation and purification of crude product by column chromatography afforded the aldol product.

(10) Breslow, R. Acc. Chem. Res. 1991, 24, 159-164.

(11) Bahmanyar, S.; Houk, K. N.; Martin, H. J.; List, B. J. Am. Chem. Soc. 2003, 125, 2475-2479.

JA0573312 
Supporting Information

\title{
Organocatalytic Direct Asymmetric Aldol Reaction in Water
}

\author{
Nobuyuki Mase, ${ }^{\dagger}$ Yusuke Nakai, ${ }^{\dagger}$ Naoko Ohara, ${ }^{\dagger}$ Hidemi Yoda, ${ }^{\dagger}$ Kunihiko Takabe, ${ }^{*}{ }^{\dagger}$ \\ Fujie Tanaka, ${ }^{\ddagger}$ Carlos F. Barbas III",
}

Department of Molecular Science, Faculty of Engineering, Shizuoka University, 3-5-1 Johoku, Hamamatsu 432-8561, Japan and The Skaggs Institute for Chemical Biology and the Departments of Chemistry and Molecular Biology, The Scripps Research Institute, 10550 North Torrey Pines Road, La Jolla, California 92037

tcktaka@ipc.shizuoka.ac.jp, carlos@scripps.edu

${ }^{\dagger}$ Shizuoka University, ${ }^{\ddagger}$ The Scripps Research Institute

General. Chemicals and solvents were purchased from commercial suppliers or purified by standard techniques. For thin-layer chromatography (TLC), silica gel plates (Merck $60 \mathrm{~F}_{254}$ ) were used and compounds were visualized by irradiation with UV light and/or by treatment with a solution of phosphomolybdic acid in ethanol followed by heating. Flash column chromatography was performed using KANTO silica gel $60 \mathrm{~N}$ (particle size $63-210 \mu \mathrm{m}$ ). ${ }^{1} \mathrm{H}$ NMR and ${ }^{13} \mathrm{C} \mathrm{NMR}$ spectra were recorded on JEOL JNM-AL spectrometer at ambient temperature. Chemical shifts are given in $\delta$ relative to tetramethylsilane (TMS), the coupling constants $J$ are given in $\mathrm{Hz}$. The spectra were recorded in $\mathrm{CDCl}_{3}$ as solvent at ambient temperature, TMS served as internal standard $(\delta=0 \mathrm{ppm})$ for ${ }^{1} \mathrm{H} \mathrm{NMR}$ and $\mathrm{CDCl}_{3}$ was used as internal standard $(\delta=77.0)$ for ${ }^{13} \mathrm{C}$ NMR. Infrared spectra were recorded on a SHIMADZU FTIR-8200A spectrometer. Mass spectra were recorded on a SHIMADZU GCMS-QP5050 spectrometer. HPLC was carried out using a SHIMADZU LC-10AD intelligent pump, SPD-10A UV detector, and C-R8A integrator. Microanalyses were performed with a Thermo Finnigan FlashEA 1112. All aldol reactions were carried out under an atmosphere of air in a closed system.

Organic substrates cyclohexanone (1a, 108-94-1), cyclopentanone (1b, 120-92-3), cycloheptanone (1c, 502-42-1), acetone (1d, 67-64-1), butan-2-one (1e, 78-93-3), pentan-3-one (1f, 96-22-0), 4-nitrobenzaldehyde (2a, 555-16-8), 4-cyanobenzaldehyde (2b, 105-07-7), 4-(methoxycarbonyl)benzaldehyde (2c, 1571-08-0), 4-bromobenzaldehyde (2d, 1122-91-4), 4-chlorobenzaldehyde (2e, 104-88-1), benzaldehyde (2f, 100-52-7), 4-methoxybenzaldehyde (2g, 123-11-5), 3-nitrobenzaldehyde (2h, 99-61-6), 2-nitrobenzaldehyde (2i, 552-89-6), L-proline (4, 147-85-3), L-prolinol (5, 23356-96-9), and $(S)-1-(2-p y r r o l i d i n y l m e t h y l) p y r r o l i d i n e ~(8 a, 51207-66-0)$ were all commercially available and were used without any purification. Catalysts $\mathbf{6 a},{ }^{1} \mathbf{6 b}, \mathbf{7},{ }^{2}$ and $\mathbf{8 b ^ { 3 }}$ were prepared by the methods previously described. ${ }^{4}$ Aldol adducts $\mathbf{3}$ are all known compounds except $\mathbf{3 n}$.

\section{References}

1. Amedjkouh, M.; Ahlberg, P. Tetrahedron: Asymmetry 2002, 13 (20), 2229-2234.

2. Sole, N.; Torres, J. L.; Anton, J. M. G.; Valencia, G.; Reig, F. Tetrahedron 1986, 42 (1), 193-198.

3. (a) Betancort, J. M.; Sakthivel, K.; Thayumanavan, R.; Tanaka, F.; Barbas, C. F., III Synthesis 2004, (9), 1509-1521. (b) Betancort, J. M.; Barbas, C. F., III Org. Lett. 2001, 3 (23), 3737-3740.

4. Asami, M. Bull. Chem. Soc. Jpn. 1990, 63 (3), 721-727.

Typical procedure for the aldol reaction using the diamine/acid bifunctional catalyst in water: The following procedure for the reaction of cyclohexanone (1a) with $p$-nitrobenzaldehyde (2a) in water using the diamine 8b/TFA bifunctional catalyst is representative. To a mixture of diamine $8 \mathbf{a}(19.0 \mathrm{mg}, 0.05 \mathrm{mmol})$ in water $(1.0 \mathrm{~mL})$ trifluoroacetic acid $(3.9 \mu \mathrm{L}, 0.05 \mathrm{mmol})$ was added at $25{ }^{\circ} \mathrm{C}$ under air in a closed system. The reaction mixture was stirred for $3 \mathrm{~min}$, then cyclohexanone $(1 \mathrm{a}, 104 \mu \mathrm{L}, 1.0 \mathrm{mmol})$ and $p$-nitrobenzaldehyde $(\mathbf{2 a}, 75.6 \mathrm{mg}, 0.5 \mathrm{mmol})$ were added. The reaction mixture was stirred for $24 \mathrm{~h}$. The reaction mixture was emulsion and the solid aldol product gradually formed from the emulsion mixture as shown in Figure 1. Water was removed by centrifugal separation. If extraction was needed, water phase was extracted with ethyl acetate $(3 \times 1 \mathrm{~mL})$, and organic extracts were dried over $\mathrm{Na}_{2} \mathrm{SO}_{4}$. Diastereoselectivity and conversion were determined by ${ }^{1} \mathrm{H}$ NMR analysis of the crude aldol product after short column chromatography purification $\left(\mathrm{SiO}_{2}, 1 \mathrm{~g}\right)$ to remove the catalyst. Purification by flash column chromatography (silica gel, hexane/AcOEt) gave the aldol product 3a as a

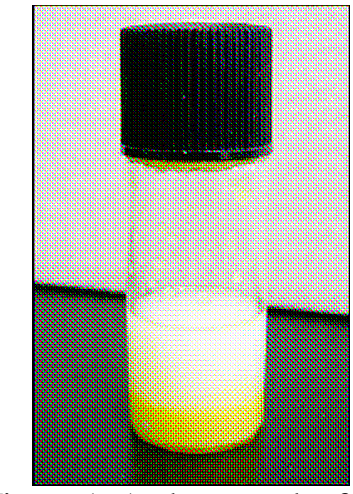

Figure 1. A photograph of the reaction mixture at $24 \mathrm{~h}$. colorless solid. The enantiomeric excess (ee) of 3a was determined by chiral-phase HPLC analysis. The absolute configuration of aldol products $\mathbf{3}$ was extrapolated by comparison of the HPLC-data with those of 3a, 3j, 31, and 3o whose absolute configuration is known. 


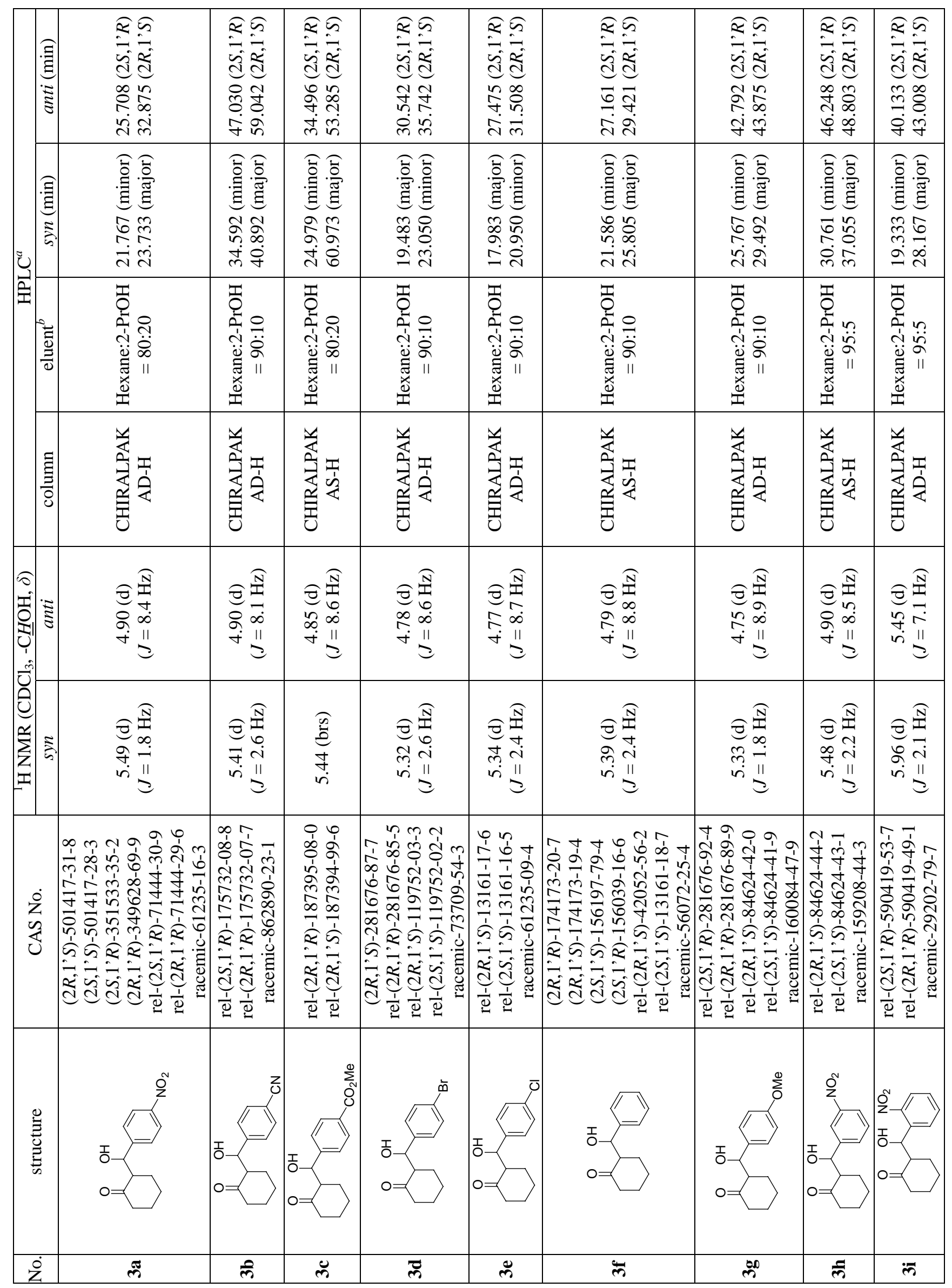




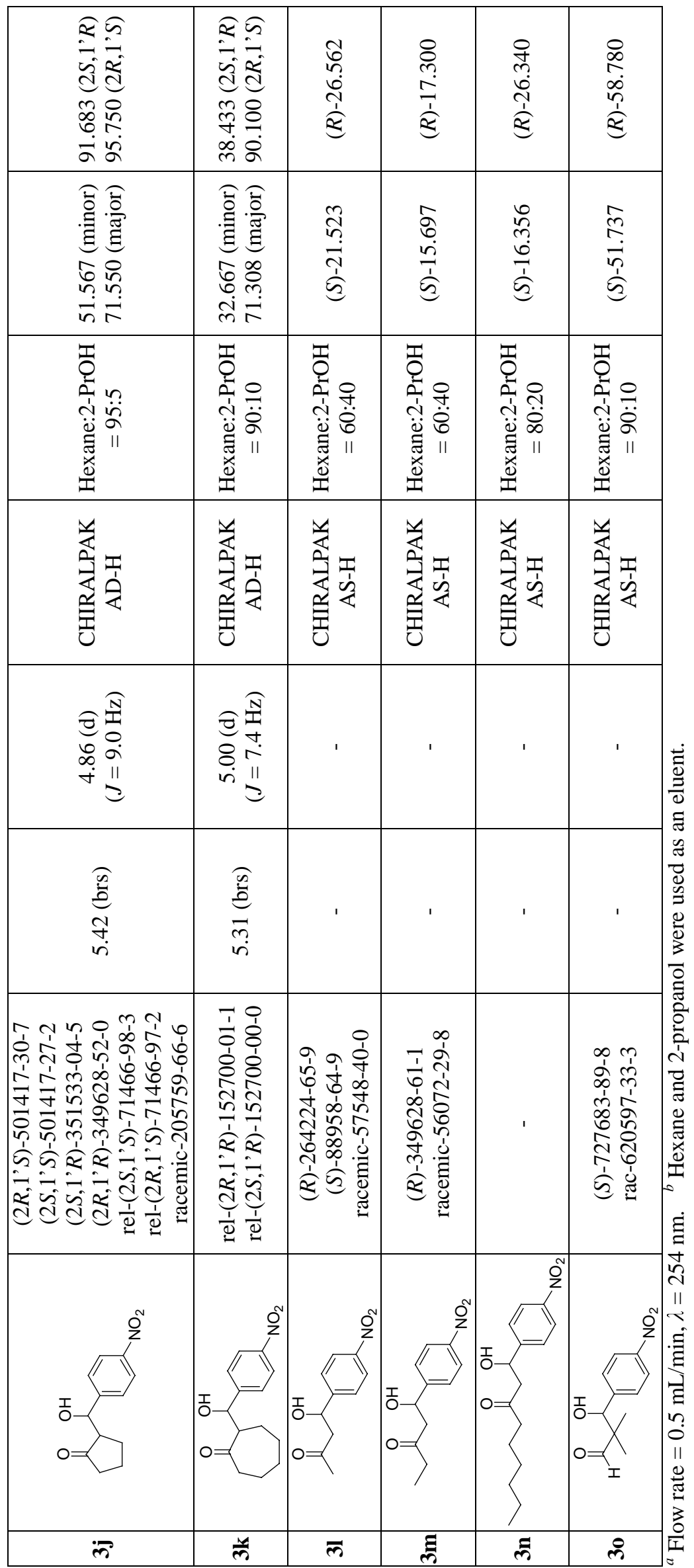


1-Hydroxy-1-(4-nitrophenyl)nonan-3-one (3n): $R_{\mathrm{f}}=0.38$ (hexane: $\left.\mathrm{AcOEt}=70: 30\right) ;{ }^{1} \mathrm{H} \mathrm{NMR}\left(\mathrm{CDCl}_{3}, 300 \mathrm{MHz}\right) \delta=0.88(\mathrm{t}$, $\left.J=6.6 \mathrm{~Hz}, 3 \mathrm{H},-\mathrm{CH}_{3}\right), 1.14-1.37\left(\mathrm{~m}, 6 \mathrm{H}, 3 \mathrm{x}-\mathrm{CH}_{2}-\right), 1.44-1.84\left(\mathrm{~m}, 2 \mathrm{H},-\mathrm{CH}_{2^{-}}\right), 2.45\left(\mathrm{t}, J=7.4 \mathrm{~Hz}, 2 \mathrm{H},-\mathrm{COC}_{2} \mathrm{CH}_{2^{-}}\right)$, 2.79-2.86 (m, 2H, -COC $\left.\underline{H}_{2} \mathrm{CH}-\right), 3.77$ (brs, $\left.1 \mathrm{H},-\mathrm{OH}\right), 5.21-5.32(\mathrm{~m},-\mathrm{C} \underline{\mathrm{HOH}}), 7.54$ (d, $\left.J=8.7 \mathrm{~Hz}, 2 \mathrm{H}, \mathrm{Ar}\right), 8.20(\mathrm{~d}, J=8.7 \mathrm{~Hz}$, $2 \mathrm{H}, \mathrm{Ar}) ;{ }^{13} \mathrm{C} \mathrm{NMR}\left(\mathrm{CDCl}_{3}, 75 \mathrm{MHz}\right) \delta=211.33(\mathrm{C}=\mathrm{O}), 150.21,147.43,126.47(\mathrm{CH}), 123.80(\mathrm{CH}), 69.02(\mathrm{CHOH}), 50.46$, 43.60, 31.41, 28.66, 23.40, 22.32, $13.85\left(\mathrm{CH}_{3}\right)$; EI-MS $279\left(\mathrm{M}^{+}, 8\right), 194\left(\mathrm{M}^{+}-n\right.$-Hex, 72$), 152\left(\mathrm{M}^{+}-n\right.$-Hex-COCH $\left.2^{-}, 88\right), 113$ $\left(\mathrm{M}^{+}-\mathrm{CH}_{2} \mathrm{CH}(\mathrm{OH}) \mathrm{Ar}, 83\right), 58$ (100); Anal. Calcd for $\mathrm{C}_{15} \mathrm{H}_{21} \mathrm{NO}_{4} ; \mathrm{C}, 64.50 ; \mathrm{H}, 7.58 ; \mathrm{N}, 5.01$. Found: $\mathrm{C}, 64.30 ; \mathrm{H}, 7.72 ; \mathrm{N}$, 5.20 .
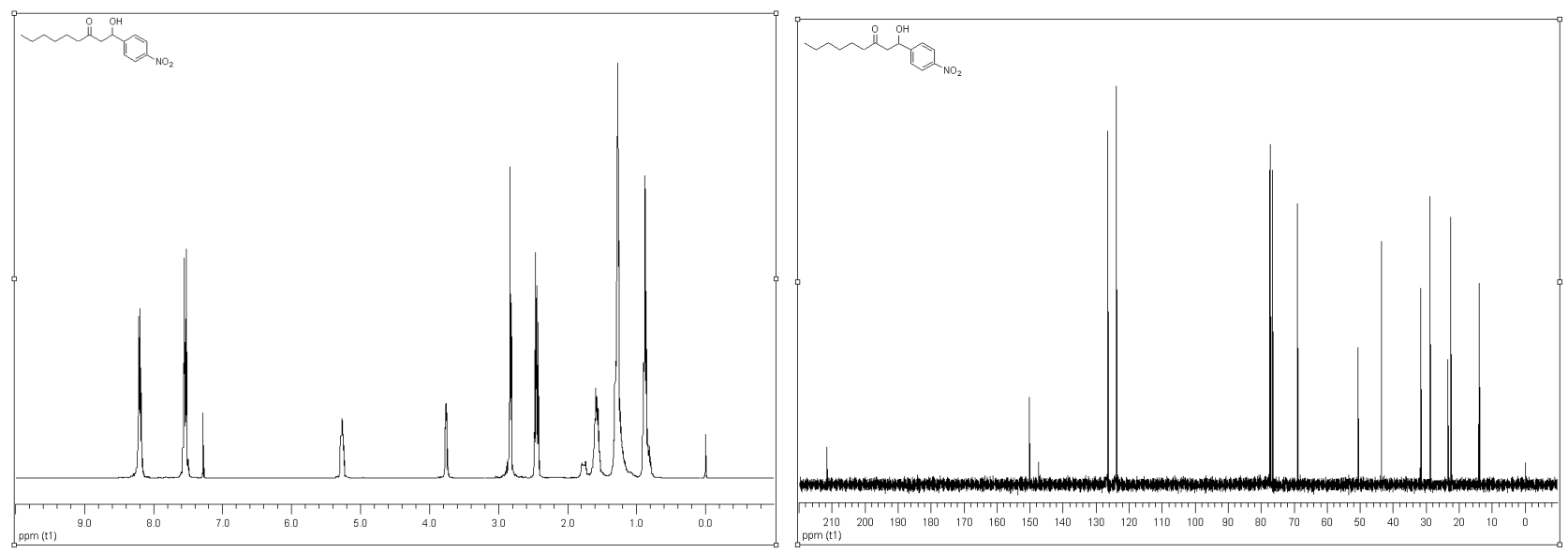